\title{
Thermal stability of water fibers: effect of the alkaline treatment - aminopropyltrimetoxysilane [Estabilidad termica de fibras de aguaje: efecto del tratamiento alcalino - aminopropiltrimetoxysilano]
}

Cesar P. Arévalo ${ }^{a}$,David A. Manyab ${ }^{b}$ Víctor R. Wong ${ }^{b}$, Aldo R. Castillo ${ }^{a}$, Hans R. Portilla ${ }^{a}$, Juan A.Vega ${ }^{a}$, Alexander Y. Vegab

a Escuela de Ingeniería Metalúrgica, Universidad Nacional de Trujillo - Av Juan Pablo s/n Trujillo, Peru

${ }^{\mathrm{b}}$ Escuela de Ingeniería de Materiales, Universidad Nacional de Trujillo - Av Juan Pablo s/n Trujillo, Peru

*alrocas@unitru.edu.pe

Received: 30 November 2020; Accepted: 03 December 2020; Published: 07 December 2020

\section{Resumen}

La presente investigación evaluó la influencia de la concentración de hidróxido de sodio y aminopropiltrimetoxysilano sobre la estabilidad térmica de las fibras de aguaje. Las fibras se extrajeron por inmersión en agua de manera manual y posterior separación por presión manual. Las concentraciones de $\mathrm{NaOH}$ fueron de $5 \%, 10 \%$ y $15 \% \mathrm{p} / \mathrm{v}$; mientras que en el caso del agente de acople silano fueron de $1 \%$ y $1.5 \% \mathrm{v} / \mathrm{v}$. Las fibras tratadas químicamente junto a las muestras testigo fueron sometidas a evaluación de análisis termogravimétrico, además se determinó de forma complementaria la variación del porcentaje de humedad, la variación química de los principales grupos funcionales de las fibras y los cambios físicos superficiales de las mismas. Los tratamientos de mercerización - silanizacion incrementan la temperatura de degradación térmicas de las fibras de aguaje, en las condiciones ensayadas este incremento fue de $3.89 \%$ en el mejor de los casos ( $5 \% \mathrm{NaOH}+1.0$ Silano). Respecto a las fibras no tratadas, los tratamientos de mercerización - silanizacion disminuyen el porcentaje de masa perdida o de degradación, en el mejor de casos esta disminución del porcentaje de masa fue de $26.85 \%$ ( $15 \% \mathrm{NaOH}+1.5$ Silano), a comparación de las fibras sin tratamiento. Finalmente, los tratamientos de mercerización -silanizacion, incrementan los porcentajes de celulosa presente en las fibras de aguaje evaluadas, mientras que la cantidad de extractivos y lignina disminuyen, en las condiciones de tratamiento químico realizadas en la presente investigación

Palabras clave: Fibras de aguaje; Agente de acople, Tratamiento alcalino.

\begin{abstract}
The present research evaluated the influence of the concentration of sodium hydroxide and aminopropyltrimethoxysilane on the thermal stability of the aguaje fibers. The fibers were extracted by manual immersion in water and subsequent separation by manual pressure. The $\mathrm{NaOH}$ concentrations were $5 \%, 10 \%$ and $15 \% \mathrm{w} / \mathrm{v}$; while in the case of the silane coupling agent they were $1 \%$ and $1.5 \% \mathrm{v} / \mathrm{v}$. The chemically treated fibers together with the control samples were subjected to thermogravimetric analysis evaluation, in addition, the variation of the humidity percentage, the chemical variation of the main functional groups of the fibers and the surface physical changes of the fibers were determined in a complementary way. The mercerization - silanization treatments increase the thermal degradation temperature of the aguaje fibers, in the conditions tested this increase was $3.89 \%$ in the best of cases $(5 \% \mathrm{NaOH}+1.0$ Silane). Regarding untreated fibers, mercerization - silanization treatments decrease the percentage of lost mass or degradation, in the best of cases this decrease in mass percentage was $26.85 \%(15 \% \mathrm{NaOH}+1.5$ Silane), compared to fibers without treatment. Finally, mercerization-silanization treatments increase the percentages of cellulose present in the aguaje fibers evaluated, while the amount of extractives and lignin decrease, under the chemical treatment conditions carried out in the present research.
\end{abstract}

Keywords: Aguaje fibers, Coupling agent, Alkaline treatment. 


\section{SE Engineering}

Vol. 4, $\mathrm{N}^{\circ} 2,2020$
Journal of Sciences and

Copyright @ 2020, CINCADER.

ISSN 2523-9503

DOI: https://doi.org/10.32829/sej.v4i2.194

\section{Introduction}

The current growth of environmental awareness generates a growing interest in the use of vegetable fibers, as reinforcements for composites of plastic matrix for domestic use and of medium structural responsibility. This is largely due to their low environmental impact, low production cost, being spontaneously degradable in the environment and relatively good specific properties. In this way, the industry has been trying to develop biodegradable compounds using renewable agricultural based materials, as they could be the fibers of the future (Kommula et al., 2015). Vegetable fibers show great potential for use in the automotive, construction and packaging industries, due to their excellent characteristics already mentioned. From a toxicological point of view, respectful to the environment and harmless, it is a good thermal and acoustic insulator with the opportunity to be a renewable resource to improve the quality of life of rural people. In this way, we can indicate that these fibers have desirable advantages over synthetic fibers; These fibers are composed of cellulose, hemicellulose, lignin, pectins, waxes, and water-soluble substances. However, the chemical composition and physical characteristics also differ with climatic conditions, age and the aging process; Likewise, the most serious drawback of these fibers is their hydrophilic nature, which causes the weak interfacial bond between the fiber and the matrix in polymer composites. Various physical impurities and the presence of hydroxyl groups on the fiber surface create difficulties to be used as high performance reinforcements, however, the mechanical performance of a composite material depends on the orientation and nature of the fibers and the matrix, the union between the fibers and the matrix also plays a very important role (Joshi et al., 2004).

The low interfacial adhesion can be improved through the use of fiber surface treatments whether by physical, chemical or natural methods. The potential uses of the fibers can include cement matrices, thermosets and thermoplastics, long fibers or strong fibers, in the case of thermoplastic matrices it is necessary to deal with the problems of low viscosity of the processing. This could hinder the correct dispersion and homogenization of the fibers and the fact of having to increase the temperature to at least transition or softening temperatures of thermoplastics, which jeopardizes the integrity of the reinforcements (Bachtiar et al., 2008). Adhesion can be resolved by chemically treating fiber surfaces before manufacturing composite materials (Wambua et al., 2003). In this way, we can conclude that surface treatments are essential to improve the adherence between natural fiber and its plastic matrix and that if it is desired to reinforce thermoplastic matrices it is necessary to increase their temperature. Therefore, the evaluation of surface treatments versus their thermal stability is necessary in order to determine the possibility of using these low-cost reinforcements in thermoplastic matrices. In this sense, the present work aimed to evaluate the thermal stability of aguaje fibers subjected to alkaline mercerization treatments (using $\mathrm{NaOH}$ ) and silanization, and thus anticipate the possible conditions of use as reinforcement in thermoplastic matrices. The aguaje palm (Mauritia flexuosa), is found in the Amazon basin of our country, being one of the most abundant plant species in the Peruvian Amazon, occupying more than 5 thousand hectares of the Peruvian Amazon. That is why it is one of the products most used by the local population, taking advantage of the fruit as a source of food, the fibers for textile manufacture, the leaves for decorating the interior of the home and wood as a source of energy; but the use of this raw material for engineering materials has not been dedicated or generated an interest, where these fibers have attractive properties for use as reinforcement in composite materials.

Sinha et al. (2017). conducted a study on Abacas fibers, these were treated with 1 and $3 \% \mathrm{NaOH}$, each one for 1 hour at $25^{\circ} \mathrm{C}$ for the purpose of improving surface adhesion, the SEM evaluation revealed that the interfacial adhesion increases with the increase in the alkali concentration. These treatments increased the surface roughness of the fibers, which allows them to adhere much better with a matrix. On the other hand Shanmugasundaram, (2018) evaluated the stem fiber of the Areca palm leaf (APLSF) extracted from an areca palm tree (Dypsislutescens) and in this case, the fibers were subjected to various concentrations of $\mathrm{NaOH}, 5 \%, 10 \%$ and $15 \% \mathrm{w} / \mathrm{v}$; it was finally determined that the density of the fibers increased, the diameter of the fibers decreased; the cellulose content increased while the hemicellulose, lignin, wax and ash content decreased; the chemical functional groups present in the fibers were confirmed by FTIR. Zhou et al. (2014), modified the surfaces of Sisal fibers using silane-type coupling agents to determine the mechanism of the chemical reaction between the fiber and the silane. To determine the effects of chemical treatment on the Sisal fiber, it was necessary to evaluate by scanning electron microscopy (SEM), Fourier transform infrared spectroscopy (FTIR), thermogravimetry (TG), differential scanning calorimetry (DSC), and mass spectrometry (TG/MS); The results showed that a film layer was formed on the surface of the fiber by adsorption of the silane consisting of siloxane and polysiloxane. Spectroscopy (FTIR) indicated that chemical 


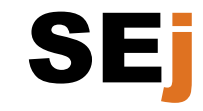

Vol. 4, $\mathrm{N}^{\circ} 2,2020$
Journal of Sciences and Engineering

Copyright (C) 2020, CINCADER.

ISSN 2523-9503

DOI: https://doi.org/10.32829/sej.v4i2.194

bonds were formed between the silane coupling agent and the fiber; TG-DSC and TG/MS analysis determined that the degradation properties of the sisal fibers changed through the formation of chemical bonds between the silane and the surface of the sisal fiber. De Rosa et al. (2011), used different chemical compounds for surface chemical treatments for vegetable fibers of Okra, among them $3.2 \%$ sodium carbonate, acetylation with $10 \%$ acetic acid, sodium hypochlorite plus acetic acid $(10 \% \mathrm{w} / \mathrm{v})$, sodium hypochlorite $(10 \% \mathrm{v} / \mathrm{v})$, sulfuric acid $1 \%$ together with potassium permanganate $0.5 \%$, sodium dodecyl sulfate $10 \%$, sodium hypochlorite $10 \%$ and $\mathrm{NaOH} 1 \%$ to the fibers, the effects of these were evaluated in tensile properties, absorption of water and thermal degradation of fibers. From the tensile data (ASTM D3379-75) and SEM evaluation, the decrease in tensile properties was determined, due to the process of delignification and degradation of cellulose chains; Likewise, according to the thermogravimetric data (TG/DTG), a decrease in the degradation temperature was observed up to $329.8^{\circ} \mathrm{C}$ with the sodium dodecyl sulfate treatment compared to the fibers without treatment, which was $349.9^{\circ} \mathrm{C}$; while the water absorption data showed significant differences between the untreated and treated fibers. This shows that the treatments reduce the hydrophilicity in Okra fibers, suggesting better adherence with hydrophobic polymer resins. Mohd et al. (2016), characterized Elephant Grass fibers, to evaluate their potential as reinforcements in plastic matrix compounds; the fibers were treated with $5,7,10,12$, and $15 \%$ by weight of sodium hydroxide for 24 h. Subsequently, they were subjected to individual tensile tests, thermogravimetric analysis (TGA), Fourier transform infrared spectroscopy (FTIR), and scanning electron microscopy (SEM), from the results we can mention that the mean diameter of the untreated fibers was $0.24 \pm 0.02 \mathrm{~mm}$, the treated fibers have a mean diameter of $0.21 \pm 0.03 \mathrm{~mm}$, producing a reduction of 12 to $45 \%$ in diameter. The moisture content of the treated fibers decreases as the alkali concentration increases. Morphological observation showed that as the alkali concentration increases, the fiber becomes more compressed due to the collapse of the lumen cell structure, the void content decreases, and the surface becomes rougher. The fiber treated with $5 \%$ alkali reached a mean maximum tensile strength of $141 \pm 24 \mathrm{MPa}$. Young's modulus averaged $5.68 \pm 0.14 \mathrm{GPa}$ for the untreated fiber and only $0.55 \pm 0.17 \mathrm{GPa}$ when alkali concentrations increased from 5 to $15 \%$. (Monteiro et al., 2012), summarized investigations that were carried out regarding thermogravimetric analysis of lignocellulosic fibers from Curauá, they could find that cellulose in a non-oxidizing atmosphere, dehydration occurs between the range of 210 to $260^{\circ} \mathrm{C}$ and the Depolymerization with volatilization occurs at approximately $310^{\circ} \mathrm{C}$, likewise as the components of hemicellulose decompose at lower temperatures of between $159^{\circ} \mathrm{C}$ and $280^{\circ} \mathrm{C}$, while lignin has three stages at lower temperatures of between $220^{\circ} \mathrm{C}$ and $250^{\circ} \mathrm{C}$, the condensation and the fragmentation of the side chains is carried out until reaching the pyrolysis of the material between $300^{\circ} \mathrm{C}$ and $400^{\circ} \mathrm{C}$. On the other hand, the compounds with Curauá fiber at different percentages of reinforcement $5 \%, 10 \%, 20 \%$ in a PU matrix showed by TG / DTG and DTA peaks of $260{ }^{\circ} \mathrm{C}$ that was assigned to the decomposition of the additives of $\mathrm{PU}$ and a major peak $422^{\circ} \mathrm{C}$, which is attributed to the decomposition of the rigid and white urethane junction. As well as in DTG, a decomposition peak was found between $358{ }^{\circ} \mathrm{C}-418^{\circ} \mathrm{C}\left(5 \%\right.$ by weight), $356^{\circ} \mathrm{C}-420{ }^{\circ} \mathrm{C}(10 \%$ by weight $)$; and $356{ }^{\circ} \mathrm{C}-418^{\circ} \mathrm{C}(20 \%$ weight), these results indicate the thermal stability of composite materials is practically equal to PU and therefore the amount of Curaruá fiber used does not cause any apparent change in thermal stability.

The thermal stability of a composite of lignocellulosic fibers is lower than a composite with a similar matrix but reinforced with glass fiber; this could be a critical constraint under conditions associated with relatively high temperatures reached during curing of the composite or its use in service; in fact, temperature usually causes degradation of the organic structure of the fiber and therefore limits the application of polymer compound. Table 1 shows the stages of the thermal degradation process of lignocellulosic fibers. 


\section{SE \\ Journal of Sciences and Engineering}

Vol. 4, $\mathbf{N}^{\circ} 2,2020$

Copyright (C) 2020, CINCADER.

ISSN 2523-9503

DOI: https://doi.org/10.32829/sej.v4i2.194

Table 1. Stages of mass loss of natural fibers (Koichi, Sreekala, Gomes, Takeshi, \& Junji, 2006).

\begin{tabular}{|c|c|c|c|}
\hline Level 1 & Level 2 & 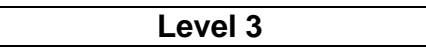 & Reference \\
\hline $\begin{array}{l}50-100^{\circ} \mathrm{C} \text { : Evaporation } \\
\text { of humidity in the fibers }\end{array}$ & $\begin{array}{l}200-300^{\circ} \mathrm{C}: \\
\text { Decomposition of } \\
\text { hemicellulose }\end{array}$ & $\begin{array}{c}400-500^{\circ} \mathrm{C}: \text { Weight loss due } \\
\text { to degradation of lignin and } \\
\text { cellulose }\end{array}$ & $\begin{array}{c}\text { (Zhou, Feng; } \\
\text { Cheng, Guangxu; } \\
\text { Jiang, Bo, 2014) }\end{array}$ \\
\hline $\begin{array}{c}300^{\circ} \mathrm{C} \text { : Corresponds to } \\
\text { the thermal } \\
\text { decomposition of } \\
\text { hemicellulose and } \\
\text { glycosidic bonds of } \\
\text { cellulose } \\
250-300^{\circ} \mathrm{C} \text { : }\end{array}$ & $\begin{array}{l}360^{\circ} \mathrm{C} \text { : Corresponds } \\
\text { to the thermal } \\
\text { decomposition of } \alpha \\
\text { cellulose }\end{array}$ & $\begin{array}{l}200-500^{\circ} \mathrm{C} \text {, máx. a } 350^{\circ} \mathrm{C} \text { : } \\
\text { lignin peak is broader and } \\
\text { appears superimposed on } \\
\text { the other two peaks }\end{array}$ & $\begin{array}{l}\text { (Hashim, Yussni; } \\
\text { Nazrul, Roslan; } \\
\text { Azriszul, Amin; } \\
\text { Ahmad, Mujahid, } \\
\text { 2012) }\end{array}$ \\
\hline $\begin{array}{l}\text { Characteristics of low } \\
\text { molecular weight } \\
\text { components, such as } \\
\text { hemicellulose }\end{array}$ & $\begin{array}{l}300-400{ }^{\circ} \mathrm{C} \text { : } \\
\text { Corresponds to } \\
\text { thermal degradation of } \\
\text { cellulose }\end{array}$ & $\begin{array}{l}\text { Cerca de } 420^{\circ} \mathrm{C} \text { : Due to the } \\
\text { decomposition of lignin }\end{array}$ & $\begin{array}{c}\text { (Nisini, E.; Santulli, } \\
\text { C.; Liverani, A., } \\
\text { 2016) }\end{array}$ \\
\hline $\begin{array}{l}220-315^{\circ} \mathrm{C} \text { : } \\
\text { hemicellulose pyrolysis }\end{array}$ & $\begin{array}{l}315-400^{\circ} \mathrm{C} \text { : cellulose } \\
\text { pyrolysis }\end{array}$ & $\begin{array}{l}\text { 160-900 C: Pyrolysis of } \\
\text { lignin } \\
\text { The highest thermal } \\
\text { decomposition of composite }\end{array}$ & $\begin{array}{l}\text { (Li, Xue; Lope, G.; } \\
\text { Satyanarayan, } \\
\text { Tabil, 2007) }\end{array}$ \\
\hline $\begin{array}{l}97^{\circ} \mathrm{C}: \text { Attributed to } \\
\text { water loss }\end{array}$ & $\begin{array}{l}325^{\circ} \mathrm{C} \text { : Attributed to } \\
\text { protein degradation }\end{array}$ & $\begin{array}{c}260^{\circ} \mathrm{C} \text { and } 390^{\circ} \mathrm{C} \text { beyond } \\
\text { the decomposition rate was } \\
\text { slow }\end{array}$ & (Ramesh, 2018) \\
\hline
\end{tabular}

The thermal decomposition of cellulose, you can establish two levels of thermal degradation: less than $200^{\circ} \mathrm{C}$. Cellulose is completely degraded by thermal effect between 325 to $375^{\circ} \mathrm{C}$. Above $300{ }^{\circ} \mathrm{C}$ there is a rapid breakdown of glycosidic bonds; By pyrolysis of cellulose, at $600{ }^{\circ} \mathrm{C}$, different products are formed such as coal, tar, water, among others (Dinwoodie, 2000). The thermal decomposition of hemicellulose is similar to that of cellulose; however, an important difference with cellulose is the decomposition rate. Thermal degradation of xylan occurs with little energy, being endothermic at 120 and $250{ }^{\circ} \mathrm{C}$ and exothermic at other values, between 50 to $300^{\circ} \mathrm{C}$; the final pyrolysis products generate tar (Li et al., 2007). The decomposition of lignin has been little studied; it is known that the degree of decomposition occurs between 250 to $500{ }^{\circ} \mathrm{C}$, being high between 310 to $420^{\circ} \mathrm{C}$; but due to its complex chemical structure, the decomposition mechanism is poorly understood; Various products are reported by pyrolysis of lignin, at $450-500{ }^{\circ} \mathrm{C}$ (Joshi et al., 2004).

\section{Materials and Methods}

2.1 Obtaining aguaje fibers. Fresh aguaje plants were brought which were dried for a period of two weeks in the sun, once the plants were dry, the fiber was extracted, with a length of approximately $20 \mathrm{~cm}$; then the stems were pressed with the help of the compression machine, which by action of pressure, it was easy to obtain the fibers, figure 1 shows the fibers obtained.
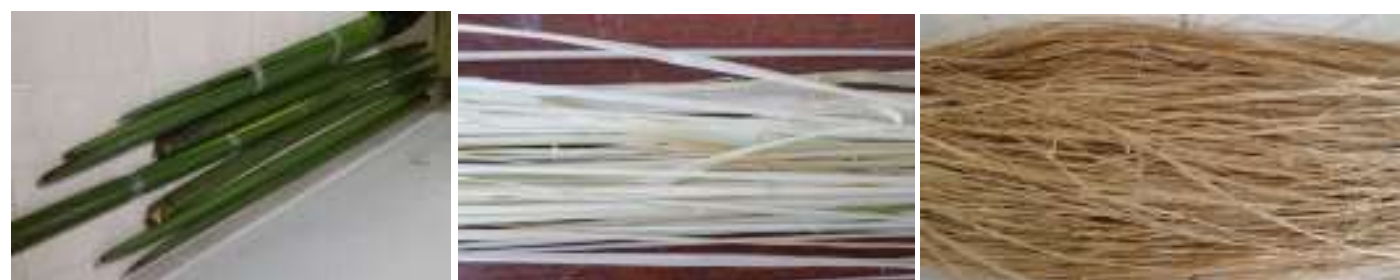

Figure 1. Fibers obtained from the Aguaje palm tree 


\section{Journal of Sciences and Engineering}

Vol. 4, $\mathrm{N}^{\circ} 2,2020$

Copyright (c) 2020, CINCADER.

ISSN 2523-9503

DOI: https://doi.org/10.32829/sej.v4i2.194

2.2 Alkaline treatment (NaOH). The fibers were distributed in packages of $40 \mathrm{~g}$ of aguaje fiber. The $\mathrm{NaOH}$ concentrations were $(5,10$ and 15$) \mathrm{g} / \mathrm{L}$ of solution, for every $40 \mathrm{~g}$ of fiber, $200 \mathrm{~mL}$ of alkaline solution was used; The solutions were cooled to $5^{\circ} \mathrm{C}$ and the immersion was carried out for 30 minutes in all cases, once the immersion stage in the alkaline solution was finished, the fibers were rinsed in distilled water, the final $\mathrm{pH}$ was 7. Finally, the fibers were dried in an oven at $80^{\circ} \mathrm{C}$ for 12 hours.

2.3 Treatment with silane. After having carried out the alkaline process, the salinization process was carried out; It was used at 1 and $1.5 \% \mathrm{v} / \mathrm{v}$ of silane dissolved in distilled water and ethanol in a volume ratio $1: 1$ $(\mathrm{v} / \mathrm{v})$, likewise a time of 1 hour was considered, at room temperature.

2.4 Moisture content of fibers. The values were obtained by mass difference, the fiber samples used were $1 \mathrm{~g} /$ test; drying temperature was $110^{\circ} \mathrm{C} / 4$ hours.

Where:

$$
\% \text { Humidity }=\left(\frac{m i-m f}{m i}\right) \times 100
$$

- $\quad \mathrm{mi}=$ initial mass

- $\quad m f=$ final mass

\subsection{Chemical analysis of fibers}

a. Fats and waxes

These compounds are quantified as follows

Where:

$$
\% \text { Fats }=\left(\frac{m 1-m 2}{m 1}\right) \times 100
$$

- $\quad \mathrm{m} 1$ : initial mass of the fiber $(\mathrm{g})$.

- $\mathrm{m} 2$ : final mass of the fiber $(\mathrm{g})$.

\section{b. Lignin}

Where:

$$
\text { Lignin }=\frac{m 2-m 3}{m 2} \times 100
$$

- $\quad$ 22: mass obtained in the fat and wax procedure (g).

- $\quad$ m3: final mass of the sample (g).

c. Cellulose

Where:

$$
\% \text { Cellulose }=\left(\frac{m 4}{m 3 *(1-H)} \times 100\right) \times \% \text { Holocellulose }
$$

- $\quad$ m3: sample mass of delignified aguaje fiber (g).

- $\mathrm{m} 4$ : final mass of the sample (g).

- $\mathrm{H}$ : humidity.

\section{d. Hemicellulose}

$\%$ Hemicellulose $=\%$ Holocellulose $-\%$ Cellulose

2.6 Thermal analysis of fibers. It was carried out in the TMA SETSYS Evo-Seteram Analyzer equipment, inert atmosphere, heating rate of $1^{\circ} \mathrm{C} /$ minute, from room temperature to $450{ }^{\circ} \mathrm{C}$.

\section{Results}

3.1 Thermogravimetric Analysis. Figure 2 shows the average characteristic curves obtained by TGA of the aguaje fiber without treatment (ST), mercerized $(5,10$ and $15 \% \mathrm{NaOH})$ and the mercerized and silanized $(\mathrm{X} \% \mathrm{NaOH}+\mathrm{Y} \% \mathrm{Si})$; For evaluation, the curves will be divided into temperature regions; In this way, the evaluation of the humidity percentage in the aguaje fibers was evaluated in the temperature range of (20 to 120) ${ }^{\circ} \mathrm{C}$; In the second range that comprises between $(120$ and 200$){ }^{\circ} \mathrm{C}$, the beginning of the decomposition 


\section{SE \\ Journal of Sciences and Engineering}

Vol. 4, $\mathbf{N}^{\circ} 2,2020$

Copyright @ 2020, CINCADER.

ISSN 2523-9503

DOI: https://doi.org/10.32829/sej.v4i2.194 of low molecular weight or extractable compounds (waxes, fats, oils) and lignin of vegetable fibers was considered; Similarly, in the range of (380 to 400$)^{\circ} \mathrm{C}$, the degradation of cellulose and lignin was evaluated. In addition to the aforementioned, the starting (Ti), end (Tf) and degradation (Tdeg) temperatures were determined for each treatment carried out, using the tangent method.

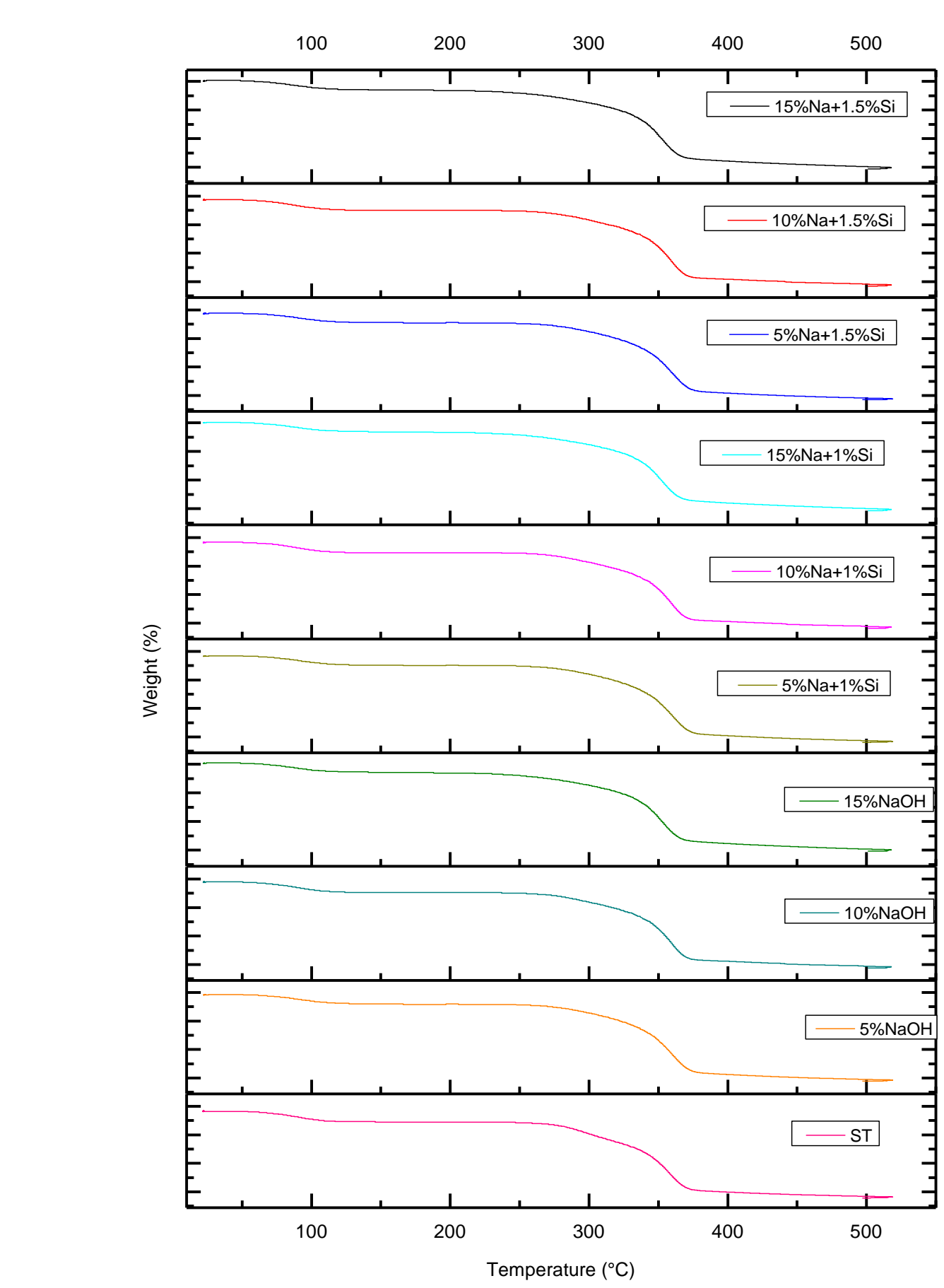

Figure 2. TGA curves of the treated and untreated aguaje fibers

\section{CINCADER}

Centre of Research and Training for

Regional Development

Online at www.journals.cincader.org 


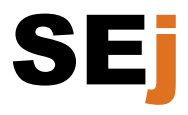

Vol. 4, $\mathrm{N}^{\circ} 2,2020$
Journal of Sciences and

Engineering

Copyright @ 2020, CINCADER.

ISSN 2523-9503

DOI: https://doi.org/10.32829/sej.v4i2.194
Centre of Research and Training for

Regional Development

Online at www.journals.cincader.org
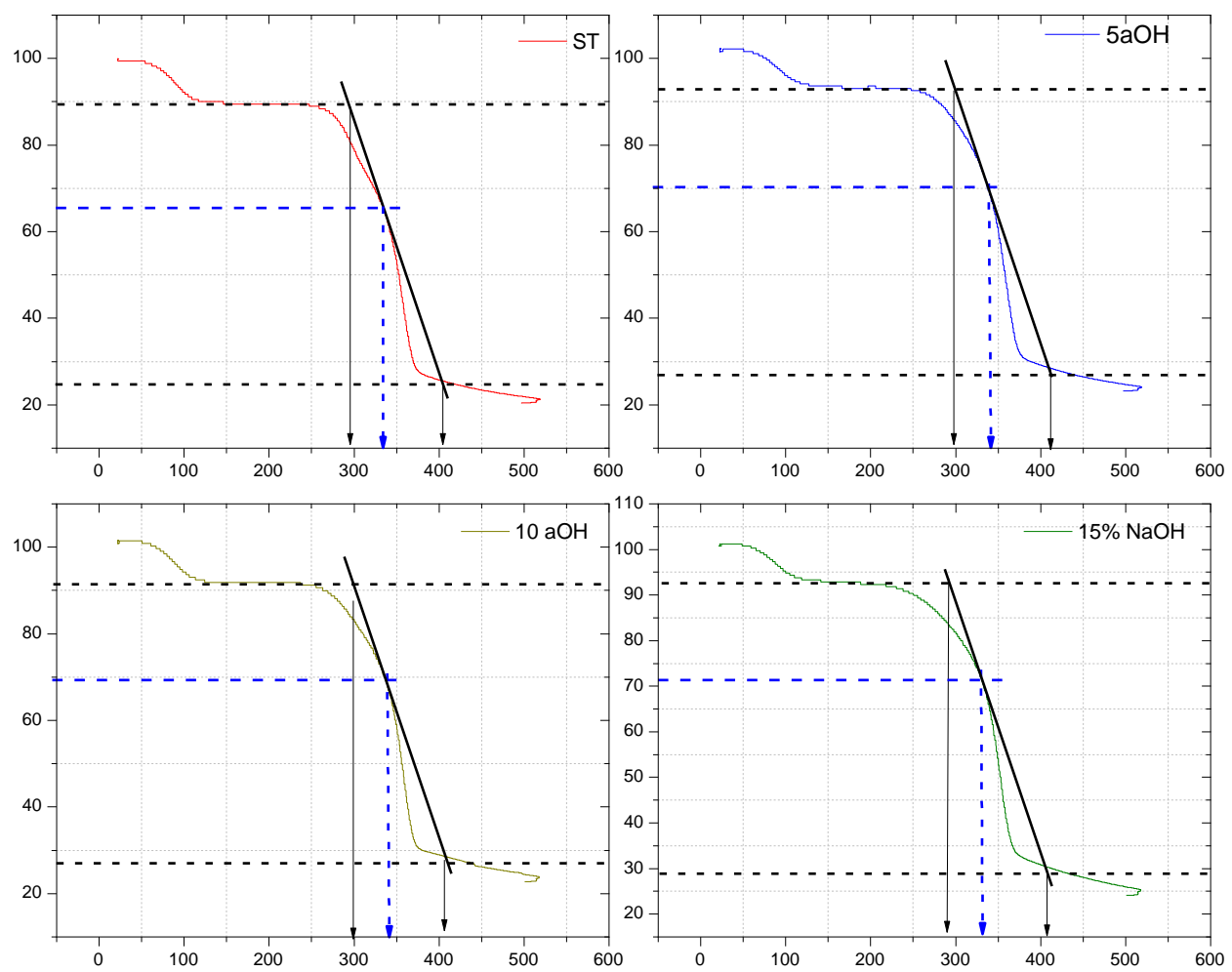

Figure 3. Determination of temperatures $\mathrm{Ti}$, $\mathrm{Tf}$ and Tdeg in aguaje fiber to different chemical treatments mercerized.

Figure 3. shows the behavior in the aguaje fibers without treatment (ST) and those subjected to alkaline treatment with $\mathrm{NaOH}$, by means of the tangent method the initial, final and degradation temperatures were determined, which are summarized in table 2 . In figure 4 , the same temperature data mentioned of the fibers are presented in this case subjected to the consecutive treatment of mercerization and silanization $(1 \% \mathrm{v} / \mathrm{v})$, finally in figure 5 , the same data are presented of temperatures mentioned of the fibers in this case subjected to the consecutive treatment of mercerization and silanization ( $1.5 \% \mathrm{v} / \mathrm{v})$. Jianqiao et al. (2018) expresses; "The high thermal stability of cellulose is attributed to the crystalline structure within this pure linear polymer, and explains that the onset of cellulose depolymerization is around $100^{\circ} \mathrm{C}$ later than the other components. Cellulose has the highest depolymerization temperature $\left(\sim 330^{\circ} \mathrm{C}\right)$ compared to lignin during TGA pyrolysis, however it has a narrower temperature range $\left(300{ }^{\circ} \mathrm{C}\right.$ to $\left.400{ }^{\circ} \mathrm{C}\right)$. As can be seen, the degradation temperatures of the aguaje fiber samples are within the degradation range considered by the present author, thus conforming to the results obtained in the present investigation. From the data presented in table 3.1 and relating the degradation temperatures with the degradation percentages, we can say that the fibers without treatment are degraded in a greater percentage equal to $43.7 \%$, as a consequence of the elimination in the first instance of low compounds. molecular weight like; water, waxes, sugars, fats, resins (De Rosa et al., 2011) and considering the temperature range from 20 to 120 , maximum humidity percentages of $9.89 \%$ in the case of TGA and $11.77 \%$ in the case of characterization. Unlike the fibers without treatment, the fibers with $15 \% \mathrm{NaOH}$, Silane mercerized treatment, have less content of low molecular weight compounds, therefore their degradation percentage is lower, also considering the nature of the treatment means of fibers that are capable of eliminating lignocellulosic compounds and substitution of $\mathrm{OH}$ - functional groups by $\mathrm{Na}+$ ions in the case of mercerization, and inclusion of coupling agents in the cases of silane and anhydride (Zhou et al., 2014). In summary, it can be deduced that the degradation percentage is higher as a 


\section{SE \\ Journal of Sciences and \\ Engineering}

Vol. 4, $\mathbf{N}^{\circ} 2,2020$

Copyright (c) 2020, CINCADER.

ISSN 2523-9503

DOI: https://doi.org/10.32829/sej.v4i2.194 consequence of having a higher content of low molecular weight components, this is the case of Monteiro et al. (2012), who expresses the following; "In the first stage of the TGA analysis, water and low molecular weight organic solvents are removed by the desorption of gases." As stated above, the idea is reaffirmed that the percentage of degradation is also a consequence of the considerable presence of low molecular weight compounds, thus it is deduced that the percentage of degradation of aguaje fiber is higher in fiber without treatment, and as a consequence is more thermally unstable and the fiber with the best thermal stability are treated aguaje fibers.
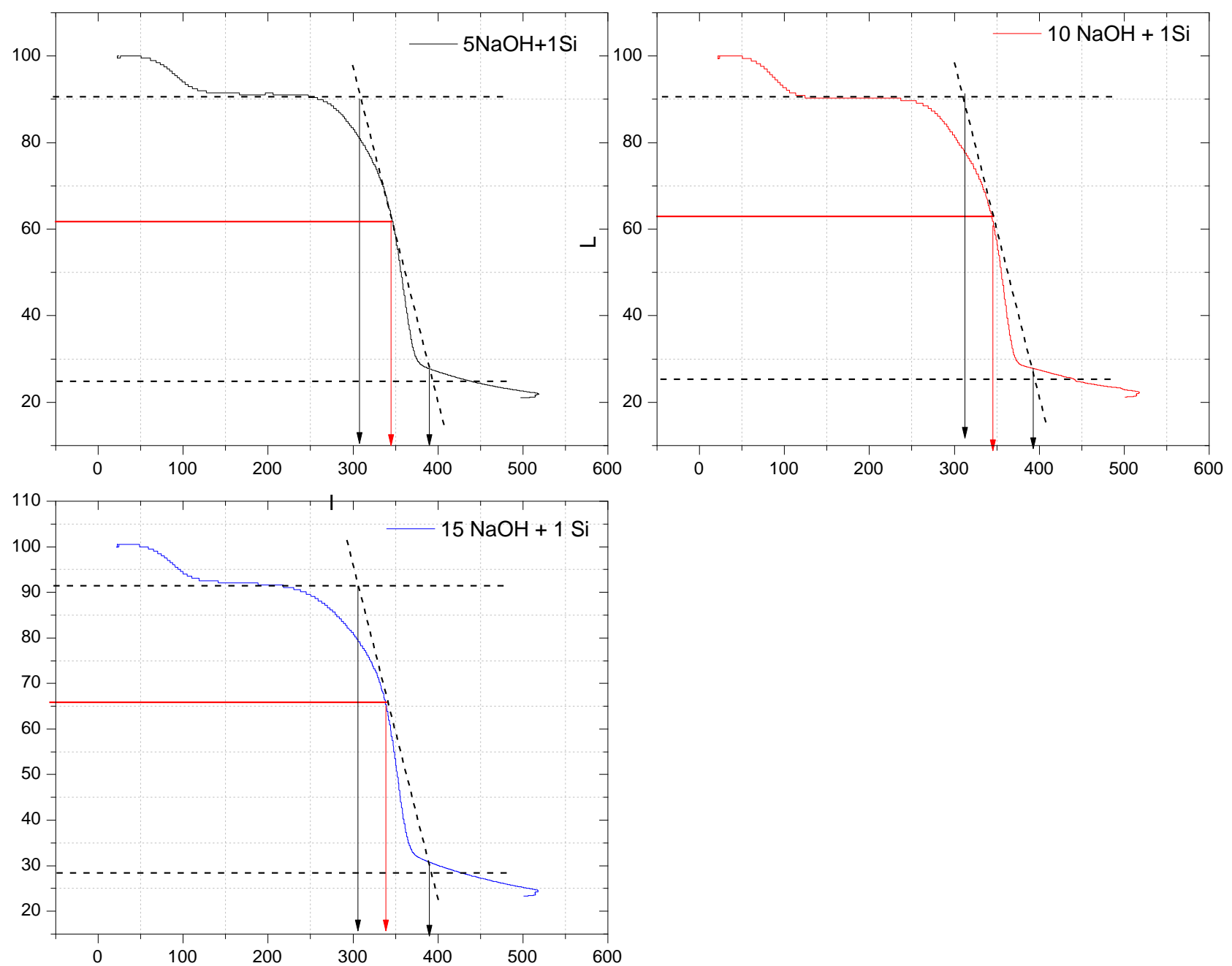

Figure 4. Determination of temperatures $\mathrm{Ti}, \mathrm{Tf}$ and Tdeg in aguaje fiber to different chemical treatments mercerized - silanized. 


\section{Journal of Sciences and Engineering}

Vol. 4, $\mathrm{N}^{\circ} 2,2020$

Copyright @ 2020, CINCADER.

ISSN 2523-9503

DOI: https://doi.org/10.32829/sej.v4i2.194
A publication of

\section{CINCADER}

Centre of Research and Training for

Regional Development Online at www.journals.cincader.org

Table 2. Temperature values $\left({ }^{\circ} \mathrm{C}\right)$ at the beginning, degradation and end of fibers

\begin{tabular}{|c|c|c|c|c|c|c|c|}
\hline Aguaje fiber & $\overline{T_{\text {initial }}}$ & Mass (\%) & $\mathrm{T}_{\text {degradation }}$ & Mass (\%) & $\overline{T_{\text {final }}}$ & Mass (\%) & Lost mass (\%) \\
\hline $15 \% \mathrm{NaOH}+1.5 \mathrm{Si}$ & 286.00 & 84.52 & 322.00 & 74.62 & 435.00 & 28.44 & 25.30 \\
\hline $10 \% \mathrm{NaOH}+1.5 \mathrm{Si}$ & 298.00 & 83.17 & 334.00 & 69.83 & 428.00 & 26.69 & 30.10 \\
\hline $5 \% \mathrm{NaOH}+1.5 \mathrm{Si}$ & 297.00 & 84.98 & 337.00 & 69.91 & 417.00 & 27.05 & 30.07 \\
\hline $15 \% \mathrm{NaOH}+1.0 \mathrm{Si}$ & 306.00 & 79.20 & 338.00 & 65.83 & 390.00 & 30.73 & 34.15 \\
\hline $10 \% \mathrm{NaOH}+1.0 \mathrm{Si}$ & 311.00 & 78.17 & 344.00 & 62.41 & 395.00 & 27.69 & 37.52 \\
\hline $5 \% \mathrm{NaOH}+1.0 \mathrm{Si}$ & 307.00 & 81.40 & 347.00 & 61.80 & 391.00 & 27.63 & 38.12 \\
\hline $15 \% \mathrm{NaOH}$ & 296.00 & 86.05 & 331.00 & 71.04 & 411.00 & 28.47 & 28.89 \\
\hline $10 \% \mathrm{NaOH}$ & 292.00 & 83.41 & 336.00 & 69.98 & 408.00 & 30.30 & 30.00 \\
\hline $5 \% \mathrm{NaOH}$ & 300.00 & 82.71 & 337.00 & 70.98 & 407.00 & 28.53 & 28.95 \\
\hline ST & 295.80 & 80.70 & 334.00 & 65.33 & 403.00 & 25.58 & 34.59 \\
\hline
\end{tabular}
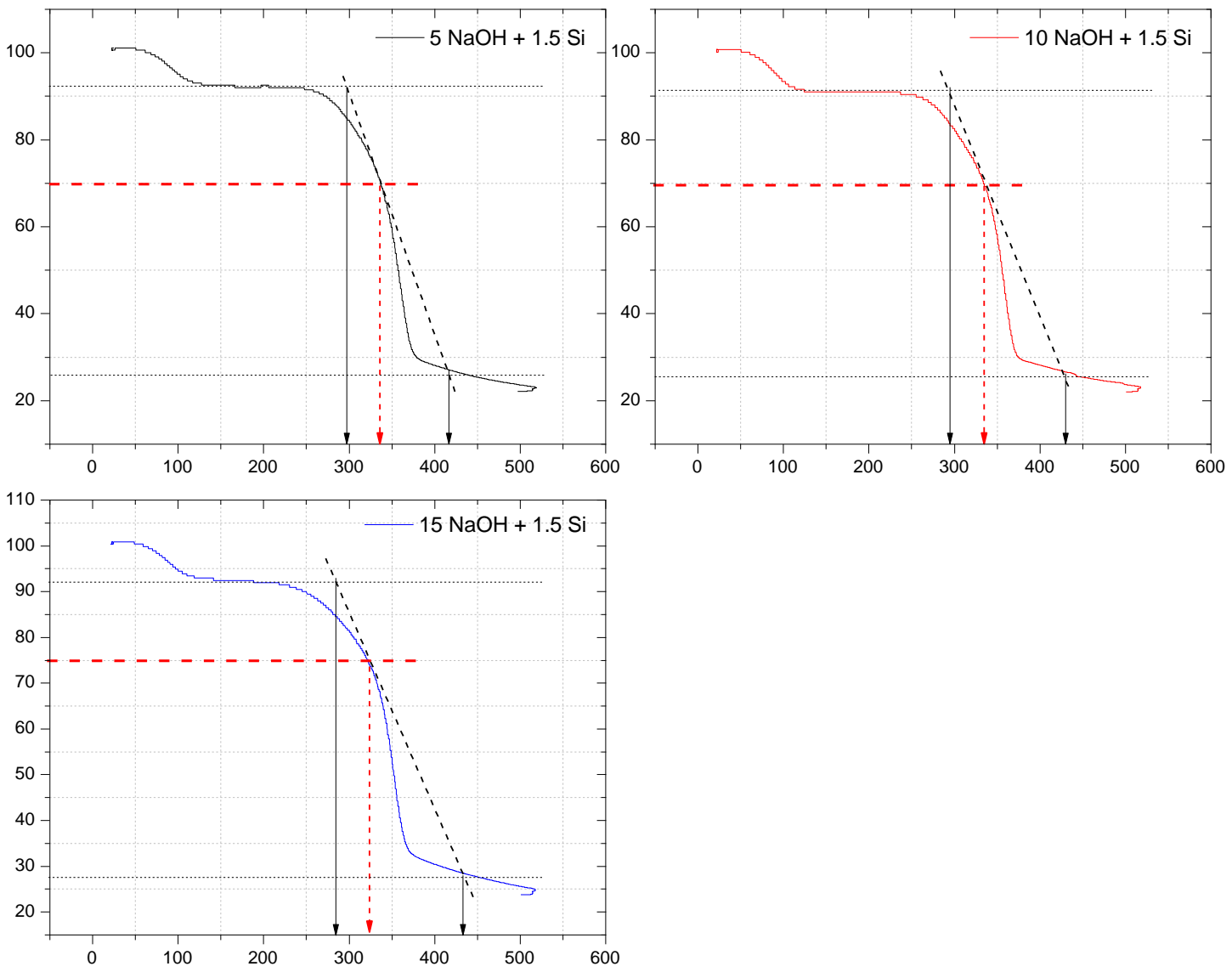

Figure 5. Determination of temperatures Ti, Tf and Tdeg of aguaje fiber to different chemical treatments mercerized - silanized 
Vol. 4, $\mathrm{N}^{\circ} 2,2020$

Copyright @ 2020, CINCADER.

ISSN 2523-9503

DOI: https://doi.org/10.32829/sej.v4i2.194

\section{SE \\ Journal of Sciences and Engineering}

Humidity. The temperature ranges from 20 to $120^{\circ} \mathrm{C}$ was considered as the first evaluation point, in this range the percentage of humidity that each of the samples tested was evaluated, this was done at a temperature of $100^{\circ} \mathrm{C}$. Table 3 summarizes what was reported.

Table 3. Initial and final weight loss percentage values, and moisture percentage of aguaje fibers with and without treatment

\begin{tabular}{ccccc}
\hline Aguaje fiber & $\begin{array}{c}\text { \% Initial } \\
\text { (\%mg) }\end{array}$ & \% Final (\%mg) & \% Humidity TGA & $\begin{array}{c}\text { \% Humidity } \\
\text { Characterization }\end{array}$ \\
\hline $15 \% \mathrm{NaOH}+1.5 \mathrm{Si}$ & 99.918 & 92.65 & 7.27 & 9.12 \\
$10 \% \mathrm{NaOH}+1.5 \mathrm{Si}$ & 99.929 & 93.47 & 6.46 & 8.78 \\
$5 \% \mathrm{NaOH}+1.5 \mathrm{Si}$ & 99.979 & 95.03 & 4.95 & 8.50 \\
$15 \% \mathrm{NaOH}+1.0 \mathrm{Si}$ & 99.979 & 94.05 & 5.93 & 8.78 \\
$10 \% \mathrm{NaOH}+1.0 \mathrm{Si}$ & 99.929 & 92.71 & 7.22 & 8.96 \\
$5 \% \mathrm{NaOH}+1.0 \mathrm{Si}$ & 99.919 & 93.96 & 5.96 & 8.12 \\
$15 \% \mathrm{NaOH}$ & 99.929 & 95.29 & 4.64 & 7.45 \\
$10 \% \mathrm{NaOH}$ & 99.979 & 94.22 & 5.76 & 7.20 \\
$5 \% \mathrm{NaOH}$ & 99.929 & 96.10 & 3.83 & 7.15 \\
$\mathrm{ST}$ & 99.918 & 92.23 & 7.69 & 10.45 \\
\hline
\end{tabular}

The data in table 3 indicate the decrease in the humidity percentage in either of the two cases, in the case of the TGA curves and the humidity percentage obtained in the characterization of the aguaje fibers. Maximum humidity percentages of $7.69 \%$ and $7.27 \%$ were obtained in the TGA analyzes and in the characterization the maximum humidity percentages of $10.45 \%$ and $912 \%$. As can be seen, the untreated aguaje fiber presents the highest percentages of humidity, because the irregular topography of the fibers makes them prone to gain water from the environment, due to their hydrophilic nature. According to Merlini et al. (2011) mention that natural fibers due to their function in the photosynthesis process are capable of conducting and storing water. Therefore, they are highly hydrophilic, this being one of the reasons why alternative treatments must be carried out, which transform or modify their surface topography and chemical instability. In the case of fibers treated with $\mathrm{NaOH}$, their moisture percentages are the lowest reported by the two methods used for evaluating the moisture percentage, being in any case different in numerical terms. The lowest values are obtained by the TGA curves in all cases. The modification of the aguaje fibers due to the mercerized treatment with $\mathrm{NaOH}$ is due to the chemical modification of the fibers, replacing the $\mathrm{OH}-\mathrm{by}$ $\mathrm{Na}+$ ions, and in the mercerizing process the elimination of lignocellulosic components such as hemicellulose and lignin, Added to this, the transformation of amorphous cellulose to crystalline, as a whole, they reduce the hydrophilic nature of the fibers, thus reducing their water absorption capacity. Corrales (2002), states that; the substitution of the $\mathrm{OH}$ - groups by $\mathrm{Na}+$ or $\mathrm{K}+$ ions depending on the nature of the hydroxide, generates chemical stability (lower absorption capacity) with the environment, thus transforming its hydrophilic to hydrophobic character, thus favoring a better adherence with a matrix polymeric, therefore, it can be deduced that the change in the topography of the aguaje fiber is evident and is reflected in the decrease in the humidity percentage in both cases. In the same way as the aguaje fiber sample without treatment, there is $92.33 \%$ of the total mass for the aguaje fiber sample mercerized with $\mathrm{NaOH}$. In the case of aguaje fibers treated with silane coupling agent, the moisture percentages for the case of TGA and characterization follow the trend shown for the mercerization process, according to Flores (2011), the decrease in moisture percentages is As a result, in the adsorption stage, reactive silanol monomers or oligomers are physically adsorbed to the hydroxyl groups of natural fibers by hydrogen bonding on the fiber surfaces (surface coating) and / or on the cell walls (mass formation of the cell wall), which depends on the molecular size of the silanol monomers / oligomers formed. Free silanols also adsorb and react with each other to form rigid polysiloxane structures linked with a stable bond -Si-O-Si-. And finally in the graft, the 


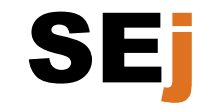

Vol. 4, $\mathrm{N}^{\circ} 2,2020$
Journal of Sciences and

Engineering

Copyright (C) 2020, CINCADER.

ISSN 2523-9503

DOI: https://doi.org/10.32829/sej.v4i2.194

hydrogen bonds between the silanols and the hydroxyl groups of the fibers can be converted into the covalent bonds of -Si-O-C- and the liberating water. Residual silanol groups on the fibers will further condense with each other. -Si-O-C- bonds may not be stable to hydrolysis; However, this union is reversible when the water is removed at a high temperature, in short, the silanes chemically modify the surface of the aguaje fiber, in our case, the silane treatments to the fibers maintain between $92.65 \%$ and $95.03 \%$ of the total mass of fiber samples. In the range of $120^{\circ} \mathrm{C}$ to $200^{\circ} \mathrm{C}$ (Table 4), low molecular weight components are degraded, considering within this range waxes, resins, oils of the complex structure of vegetable fibers (Monteiro and others, 2012). Consequently, the fiber with a higher content of these components should present a higher percentage of degradation or, failing that, this higher percentage would be due to the protective effect of the coatings generated in the chemical processes to which the fibers were subjected. In the case of fiber without treatment (ST) at a temperature of $200^{\circ} \mathrm{C}$, the elimination of these components and starts the process of degradation of lignin, in this way it only presents $89.48 \%$ of the total weight, in the case of the fibers treated by mercerization $(5,10$ and 15$) \% \mathrm{NaOH}$, the mass percentages remain between $91.80 \%$ and $93.59 \%$, which indicates the little difference in the concentrations used, in these cases the effect of temperature being that of more influence apparently. For the cases of mercerized and subsequently silaned fibers, these fibers present a range of between $90.29 \%$ and $92.52 \%$ of non-lost mass, up to a temperature of $200^{\circ} \mathrm{C}$, after evaluating these data, we can infer that the chemical treatments to which the fibers were subjected, although they generate modifications in the thermal behavior, these are not large in quantitative terms, which would demonstrate the little variation of the compounds removed in the mercerizing process (controlled degradation of fibers), table 3.4 shows the results of the chemical quantification of the components of the treated fibers.

Table 4. Percentage masses of fibers in TGA test in the range of 120 to $200^{\circ} \mathrm{C}$.

\begin{tabular}{cccc}
\hline & \multicolumn{3}{c}{ Mass (\%) } \\
\hline & & Temperatures & \\
$15 \% \mathrm{NaOH}+1.5 \mathrm{Si}$ & 92.94 & $200{ }^{\circ} \mathrm{C}$ & 0.99 \\
$10 \% \mathrm{NaOH}+1.5 \mathrm{Si}$ & 91.65 & 91.95 & 0.61 \\
$5 \% \mathrm{NaOH}+1.5 \mathrm{Si}$ & 93.02 & 91.04 & 0.5 \\
$15 \% \mathrm{NaOH}+1.0 \mathrm{Si}$ & 92.56 & 92.52 & 0.99 \\
$10 \% \mathrm{NaOH}+1.0 \mathrm{Si}$ & 90.90 & 91.57 & 0.61 \\
$5 \% \mathrm{NaOH}+1.0 \mathrm{Si}$ & 91.95 & 90.29 & 0.5 \\
$15 \% \mathrm{NaOH}$ & 93.31 & 91.45 & 0.99 \\
$10 \% \mathrm{NaOH}$ & 92.41 & 92.32 & 0.61 \\
$5 \% \mathrm{NaOH}$ & 94.09 & 91.80 & 0.5 \\
$\mathrm{ST}$ & 90.04 & 93.59 & 0.56 \\
\hline
\end{tabular}

Table 5. Chemical quantification of aguaje fiber

\begin{tabular}{ccccc}
\hline Aguaje fiber & \% Fats & \%Cellulose & \%Lignin & \%Hemicellulose \\
\hline ST & 20.15 & 62.45 & 8.388 & 9.01 \\
$5 \% \mathrm{NaOH}$ & 19.12 & 63.66 & 8.578 & 8.64 \\
$10 \% \mathrm{NaOH}$ & 18.92 & 64.3 & 8.448 & 8.33 \\
$15 \% \mathrm{NaOH}$ & 17.5 & 66.18 & 8.358 & 7.96 \\
$5 \% \mathrm{NaOH}+1.0 \% \mathrm{Si}$ & 18.12 & 64.56 & 8.378 & 8.94 \\
$10 \% \mathrm{NaOH}+1.0 \% \mathrm{Si}$ & 17.92 & 64.96 & 8.488 & 8.63 \\
$15 \% \mathrm{NaOH}+1.0 \% \mathrm{Si}$ & 17.32 & 66.98 & 6.808 & 8.89 \\
$5 \% \mathrm{NaOH}+1.5 \% \mathrm{Si}$ & 18.05 & 65.16 & 7.828 & 8.96 \\
$10 \% \mathrm{NaOH}+1.5 \% \mathrm{Si}$ & 17.69 & 65.01 & 8.708 & 8.59 \\
$15 \% \mathrm{NaOH}+1.5 \% \mathrm{Si}$ & 17.15 & 67.12 & 7.538 & 8.19 \\
\hline
\end{tabular}


The data in table 5, shows the percentages by weight of the lignocellulosic components of the aguaje fibers reported in the present investigation; This corroborates what is reported in the range of 120 to $200{ }^{\circ} \mathrm{C}$, that is, the little variation in the chemical variation of the fibers evaluated, however the decrease in fats with the treatments carried out (mercerization and silanization) is evident, a tendency The opposite shows the percentages of cellulose, on the other hand lignin and hemicellulose tend to decrease in the case of lignin and increase in the case of hemicellulose (although these differences are quantitatively small). In temperature ranges from $250^{\circ} \mathrm{C}$ to $400^{\circ} \mathrm{C}$, cellulose degrades, from $400^{\circ} \mathrm{C}$ mainly lignin degrades, a greater degradation of the fiber without treatment due to the presence of higher lignin content and due to so much greater percentage by weight of this component is lost, at temperatures higher than $400{ }^{\circ} \mathrm{C}$. Therefore, we can deduce that; the lignin content is inversely proportional to the residual percentage of the total weight of the fibers with and without treatment. Nisini et al. (2016), expresses the following "cellulose from aguaje fiber degrades in a range of 300 to $400^{\circ} \mathrm{C}$ and lignin in a range of $160^{\circ} \mathrm{C}$ to $900{ }^{\circ} \mathrm{C}$, as a result of the interaction of cellulose, hemicellulose and lignin during pyrolysis, because cellulose is always connected with hemicellulose and lignin through hydrogen bonds, while hemicellulose is linked to lignin with covalent bonds and hydrogen". Based on the above, it can be said that these components do not degrade independently and in the case of lignin and cellulose they are united and have a higher degradation temperature than hemicellulose. Jianqiao et al. (2018), states that; lignin is the most stable component that can be decomposed at a higher temperature range of $300-550^{\circ} \mathrm{C}$. From the present graph, it is considered that the aguaje fiber sample treated with maleic anhydride is thermally more stable, as a result of which it presents a lower percentage weight loss, compared to the other aguaje fiber samples with and without treatment.

\section{Conclusions}

- The mercerization - silanization treatments increase the thermal degradation temperature of the aguaje fibers, in the tested conditions this increase was $3.89 \%$ in the best of cases $(5 \% \mathrm{NaOH}+$ 1.0 Silane), with respect to the untreated fibers.

- Mercerization - silanization treatments decrease the percentage of mass loss or degradation, in the best of cases this decrease in mass percentage was $26.85 \%(15 \% \mathrm{NaOH}+1.5$ Silane), compared to the fibers without treatment.

- Mercerization-silanization treatments increase the percentages of cellulose present in the aguaje fibers evaluated, while the amount of extractives and lignin decrease, under the chemical treatment conditions carried out in the present investigation.

\section{Acknowledgments}

A very special thanks to the Laboratory of Copied Materials of the School of Materials Engineering of the Universidad Nacional de Trujillo for the facilities provided for the development of this research.

\section{References}

Bachtiar, D., Sapuan, SM, Hamdan, MM. 2008. The effect of alkaline treatment on tensile properties of sugar palm fibre reinforced epoxy composites. Materials \& Design. 29. 1285-1290. 10.1016/j.matdes.2007.09.006.

Corrales, F. 2002.Modificació de fibres de jute per l'elaboració de plástics reforcats. Universidad Politecnica de Cataluña, Cataluña-España.

De Rosa, Igor, Kenny, Jose Mohd. Maniruzzaman, Md. Moniruzzaman, Marco Monti, Debora Puglia, Carlo Santulli, Fabrizio Sarasini. 2011, Effect of chemical treatments on the mechanical and thermal behaviour of okra (Abelmoschus esculentus) fibres, Composites Science and Technology, Volume 71, Issue 2.

Dinwoodie, J. 2000, Timber: its nature and behaviour. E \& FN Spon, 2, 46-58.

Flores, N. 2011. Efecto del tratamiento quimico en las propiedades fisicas y mecanicas de las fibras de musa paradisiaca L para refuerzos en composites. Guayaquil, Ecuador: Epsol. 


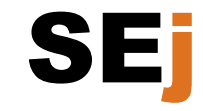

Vol. 4, $\mathrm{N}^{\circ} 2,2020$

\section{Journal of Sciences and Engineering}

Copyright (C) 2020, CINCADER.

ISSN 2523-9503

DOI: https://doi.org/10.32829/sej.v4i2.194

Hashim, Yussni; Nazrul, Roslan; Azriszul, Amin; Ahmad, Mujahid. 2012, Mercerization Treatment Parameter Effect on Natural Fiber Reinforced Polymer Matrix Composite: A Brief Review. World Academy of Science, 68.

Jianqiao, W., Boxiong, S., Dongrui, K. 2018. Investigate the interactions between biomass components during pyrolysis using in-situ DRIFTS and TGA. Chemical Engineering Science - EISevier. doi:https://doi.org/10.1016/j.ces.2018.10.023

Joshi , S., Drzal , L., Mohanty, A., Arora, S. 2004. Are natural Flber composites environmentally superior to glass fiber reinforced composites?. Compos Part A(35), 371-376. 10.1016/j.compositesa.2003.09.016.

Koichi, G., Sreekala, M., Gomes, A., Takeshi, K., Junji, O. 2006. Improvement of plant based natural fibers for toughening green composites-Effect of load application during mercerization of ramie fibers. Composites - EISevier, 2213-2220

Kommula, V P, Obi Reddy, K., Shukla, Mukul, Marwala, Tshilidzi, Reddy, E., Rajulu, A. 2015. Extraction, Modification, and Characterization of Natural Ligno-Cellulosic Fiber Strands From Napier Grass. International Journal of Polymer Analysis and Characterization. 21. 150911084612000. 10.1080/1023666X.2015.1089650.

Li, X., Tabil, L., Panigrahi, S. 2007. Chemical Treatments of Natural Fiber for Use in Natural Fiber-Reinforced Composites: A Review. Journal of Polymers and the Environment. 15. 25-33. 10.1007/s10924-006-00423.

Merlini, C., Soldi, V., Barra, G. 2011. Influence of fiber surface treatment and length on physico-chemical properties of short random banana fiber-reinforced castor oil polyurethane composites. Polymer Testing - POLYM TEST. 30. 833-840. 10.1016/j.polymertesting.2011.08.008.

Monteiro, S., Calado, V., Sanchez Rodriguez, R., Margem, F. 2012. Thermogravimetric Stability of Polymer Composites Reinforced with Less Common Lignocellulosic Fibers - an Overview. Journal of Materials Research and Technology. 1. 117-126. 10.1016/S2238-7854(12)70021-2.

Nisini, E., Santulli, C., Liverani, A. 2016. Mechanical and impact characterization of hybrid composite laminates with carbon, basalt and flax fibres. Composites Part B: Engineering. 127. 10.1016/j.compositesb.2016.06.071.

Ramesh, M. 2018. Flax (Linum usitatissimum L.) fibre reinforced polymer composite materials: A review on preparation, properties and prospects. Progress in Materials Science. 102. 10.1016/j.pmatsci.2018.12.004.

Ridzuan, MJ., Abdul Majid, M.S., Afendi, M., Kanafiah, A., Zahri, J.M., Gibson, A.G. 2016. Characterisation of natural cellulosic fibre from Pennisetum purpureum stem as potential reinforcement of polymer composites. Materials and Design. 89. 839-847. 10.1016/j.matdes.2015.10.052.

Shanmugasundaram, N. 2018. Characterization of untreated and alkali treated new cellulosic fiber from an Areca palm leaf stalk as potential reinforcement in polymer composite.

Sinha, Agnivesh \& Narang, Harendra \& Bhattacharya, S. 2017. Effect of Alkali Treatment on Surface Morphology of Abaca Fibre. Materials Today: Proceedings. 4. 8993-8996. 10.1016/j.matpr.2017.07.251.

Wambua, P., Ivens, J., Verpoest, I. 2003. Natural fibres: Can they replace glass in fibre reinforced plastics? Composites Science and Technology. 63. 1259-1264. 10.1016/S0266-3538(03)00096-4.

Zhou, F., Cheng, G., Jiang, B. 2014. Effect of silane treatment on microstructure of sisal fibers. Applied Surface Science. 292. 10.1016/j.apsusc.2013.12.054. 